\title{
Three Incomplete Limestone Stelae from Ihnasya el-Medina (Herakleopolis Magna)
}

\author{
Hayam H. RAWASH \\ Faculty of Archaeology, Cairo University, Egypt \\ E-mail: hhafez762@gmail.com
}

الملخص

\begin{abstract}
This article deals with publication of three unpublished incomplete limestone stelae from Ihnasya El-Medina necropolis. The first stela was found in 2010, during work digging for a water-pipe project at the depth of five meters underground in front of El-Masharka district. The second and the third stelae were found by some thieves in the region of Ihnasya city. The police officers found two stelae and filed the report under the misdemeanor number 4083/Ihnasya 2009. These stelae were dedicated to the gods Osiris and Anubis; and are now preserved in Ihnasya El-Medina Magazine.

Publishing these three stelae in one article due to that they are from one area, and it seems that they have the same type.
\end{abstract}

\section{KEYWORDS}

Limestone Stelae - Ihnasya el-Medina -

Herakleopolis Magna - Incomplete Stelae false door

\section{INTRODUCTION}

The stelae have lost some fragments which are revealed by comparisons between the remains of the right and left sides which contained hieroglyphs and the titles of the stela's owner, as well as between similar stelae from the same period inside Ihnasya necropolis and others. As to the first and the second stelae; comparison can be found, such as the stela of Ndmwi (Inv.Nr.2502/Ihnasya 2007), the stela of Ipj-ḩ3.iš.wt.f (Inv.Nr.2535/Ihnasya
يتناول هذا البحث نشر ودراسة ثلاثة لوحات غير مكتملة

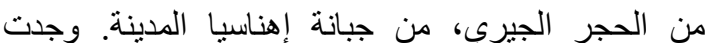

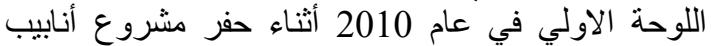

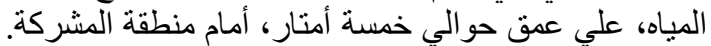

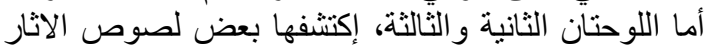

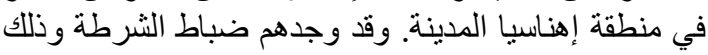

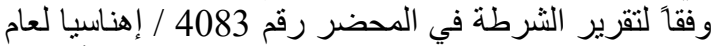

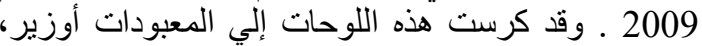

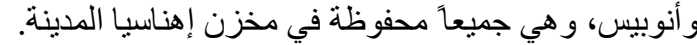

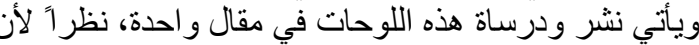
الددينة، وتنتمي اللوحات إلي نفس النوع من اللوحات.

الكلمات الدالة - الة

$$
\text { لوحات من الحجر الجبري - إهناسيا المدينة - هير اكلوبوليس }
$$

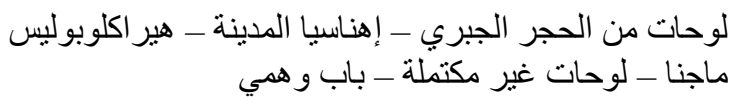


2010), ${ }^{1}$ the stela of hnm-htp N.25 Dahshour necropolis), ${ }^{2}$ and the stela of Nny (N.28 Dahshour necropolis) ${ }^{3}$. As for the third stela; one may find comparisons in similar stelae, such as some discovered by the Spanish missions at Ihnasya el-Medina, (register numbers 199, 208, and 408). Through these comparisons we can trace the missing parts of these stelae as follows:

\section{[1] - Stela of Ipi $\square \bigcap_{(P I .1, \text { fig.1) }}$}

A false door stela is belonging to an individual called Ipi.

Material: limestone. Measurement: 60 x 50 x $15 \mathrm{~cm}$.

Place of preservation: Ihnasya El-medina Magazine (Inv. Nr. 2611/ Ihnasya 2011).

State of preservation: The relief and hieroglyphs are in a fairly good state of preservation, rendered in sunken relief.

\section{Description}

The stela is divided into three registers. The first register represents the remains of the lintel of the stela, which usually appears under the jambs of similar examples. The first part of the lintel has lost its horizontal section, but would have contained horizontal hieroglyphs with two formulas of $h t p-d i-n s w$. The first one begins at the right side of the stela, which as usual, contained the well-known formula for the god Osiris, an offering invocation, title and the name of the owner of the stela Ipi. The second register represents the left side of the stela, which is mostly lost except the title $i m 3 h w$ and the remains of the owner's figure. Most of the second formula which should be begin on the left side of the stela, was lost, it would usually end with the well-known formula for the god Anubis, offering invocations, titles and the name of the owner of the stela Ipi. But we have only the owner's titles and his name with his figure. The third register represents the middle of the stela which usually is containing the cornice; below it are twelve colored flower petals, painted dark yellow and red. These petals separated the lintel of the stela from its main panel. Below is a figure of the stela's owner Ipi, who is seated before the offering table in the center of the stela and surrounded by a molding in the shape of square. Lying on this table are typical items; a woven mat, a heap of food, and a goose. Under the offering table there are the hs jar, and the pan and jar, which were used in the purification of the deceased. They had a magical significance, meaning that the deceased became free of his sins. ${ }^{4}$ Most of the traditional offering formula was lost but through the remains of some letters, one can read as follow "An offering consisting of a thousand of bread, a thousand of beer, a thousand of oxen, a thousand of fowl, a thousand of ointment-jars and a thousand of clothing for the ba of 'Ipi. The stela's owner figure is seated before the offering table and he is gripping a piece of cloth in the left hand and holding it toward his chest while the right hand extended towards the table. Ipi was depicted sitting on a low lion leg chair with back support. Below the owner's figure there are remains of a false door which helps the $k 3$ of 'Ipi to go back and forth through it, enabling him to see what was happening outside the tomb.

\footnotetext{
${ }^{1}$ Rawash, 'Two Unpublished Stelae from Ihnasya EL-Medina', The scientific magazine of South Valley University, vol. 9 (2014), 505-525.

${ }^{2}$ De-Morgen, Fouilles à Dahchour, (Vienne,1895), 38, fig.79; the stela is preserved now in Cairo museum (CG 1478).

${ }^{3}$ De-Morgen, Fouilles à Dahchour, .40, fig.81, The present location of this stela is unknown.

${ }^{4}$ Gardiner, 'The Baptism of the Pharoh', JEA 36 (1950), 3.
} 


\section{Texts}

Most of the upper part of the lintel was lost; these usually is containing, in their upper parts horizontal hieroglyphs written from the middle, two formulae of $h t p d i n s w$. The details of the first one, which run right to left, were lost:

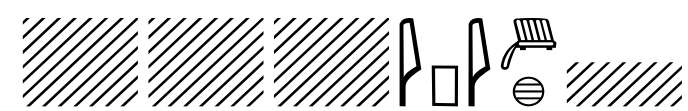

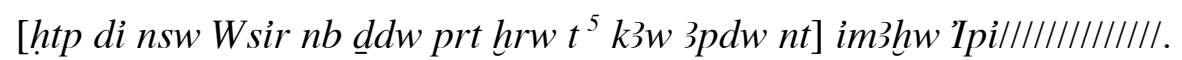

[May the king give a boon (to) the god Osiris lord of Busiris, invocation offerings from bread, oxen, and fowl of] the revered Ipi ////I/I/I/I/I/I/I/I/I/I/I.

Most of the details of the second line, which begins on the left side, were lost:

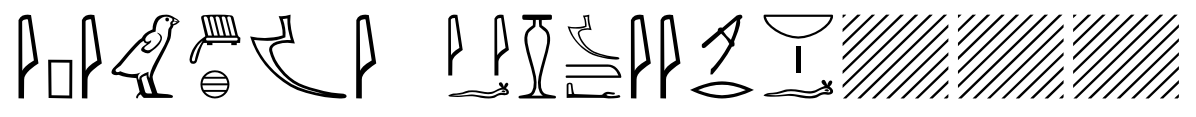

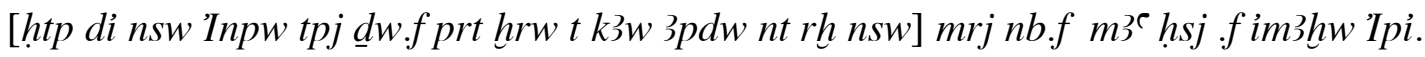

[May the king give a boon (to) the god Anubis who upon its hill, invocation offerings from bread, oxen, and fowl of the king's acquaintance] the real beloved by his master, his praised one, the revered 'Ipi.

The third register is containing a figure of the stela owner Ipi, who is seated before the offering table, which as usual supported a woven mat, a heap of food, and a goose. Most of the traditional offering formula was lost but one can read the text as following:

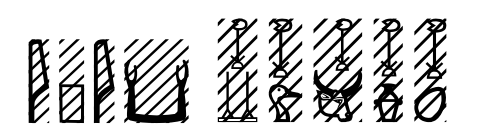

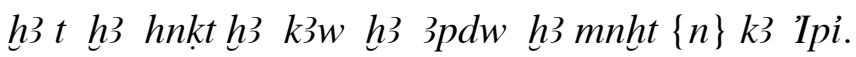

[An offering consisting of] a thousand of bread, a thousand of beer a thousand of oxen, a thousand of fowl \{for\} the spirit of "Ipi".

\section{Comment}

a- This type of stela undoubtedly dated to the First Intermediate Period or the beginning of The Middle Kingdom 2160-1950 BC, because the shape of the stela was very popular during these periods ${ }^{6}$.

b- The owner of the stela's name 'Ipi was attested from The Old Kingdom, ${ }^{7}$ the First Intermediate, ${ }^{8}$ the Middle Kingdom Periods, ${ }^{9}$ and was still used in the New

\footnotetext{
${ }^{5}$ Wb I, 528-529; Speleer, Textes de Cercueils, (Paris, 1946), $171 \mathrm{~b}$.

${ }^{6}$ Revise many similar stelae from the same periods inside Ihnasya necropolis itself or outside it, see the introduction.

${ }^{7}$ PN.I, 22; Petrie Deshasheh. Egypt Exploration Fund Fifteenth Memoir, (London,1898), 1.6; PM.IV, 161-162; PM.III, 540; Wreszinski, Atlas zur altaegyptischen Kulturgeschichte I, (Leipzig 1923),18 and texts to Taf.18; Smith, A History of Egyptian Sculpture and Painting in the Old Kingdom, (London\&Boston,1978), pl.56 (b), 208-222; PM.III, 161-2; Garlstang, The Burial Customs of Ancient Egypt as illustrated by Tombs of the Middle Kingdom, (London,1907), 36-41, figs.25-8, 188, 167-72, figs.173-7; from Naga el-Deir, PM. V, 26.
} 
Kingdom, ${ }^{10}$ and Late Periods (2160-1950 BC). ${ }^{11}$ During the excavations, were done by the Spanish mission in Ihnasya el-Medina from 1966-2010. Many false doors stelae were discovered containing the name Ipi, ${ }^{12}$ so this name is considered the second most popular name in Ihnasya after the famous name $h t j$.

c- The main title of 'Ipi is lost, the main titles are usually carved on the jamb and the right side of the stela, and these two pieces are missing. The beginning of the traditional title ${ }^{13}$ of Ip $i$ is lost, but with the existing fragments it can be reconstructed as:

[rh nsw] mrj nb.f m3' hsj ff im3hw 'Ipi: 'The king's acquaintance, the real beloved of his master, his praised one, the revered 'Ipi'. ${ }^{14}$ These titles were found on many stelae at Ihnasya el-Medina. ${ }^{15}$ The main title $\left[\begin{array}{ll}r h & n s w\end{array}\right]$ 'the king's acquaintance' ${ }^{16}$, was a dignitary title, but it sometimes indicates to a religious job related to the god Osiris, especially if it listed with other religious titles ${ }^{17}$. This title was common in the tombs of the different necropolises of the First Intermediate Period and the beginning of The Middle Kingdom, for instance the tomb of Impy in Kom ELFakhry necropolis ${ }^{18}$

d- The main offering formula $h t p-d i-n s w^{19}$ which was recorded on stelae of the First Intermediate, and the Middle Kingdom was the $h t p-d i-n s w$, dedicated mainly to the gods Osiris ${ }^{20}$ and Anubis ${ }^{21}$, which had many roles related to the deceased in the

\footnotetext{
${ }^{8}$ PM.I, 389; PM.V, 26; Wainwright, 'Three Stelae From Naga el-Deir', ASAE 25 (1915), 164-166, pl. I-III.

${ }^{9}$ Newberry, Beni Hasan I, (London,1893), pl.20; R. Anthes, 'Die Felseninschriften von Hatnub', in: K.Sethe (ed.), Untersuchungen zur Geschichte u.Altertamskunde Ägypten, herausg V. G. Steindorff.Bd.g., (Leipzig,1928); Berlin7779c; Florenz, Schiaparelli1538; Anthes, Hatnub, 1.27; Graffiti 40; Brit.Mus.851; Cairo 20313.g; PN.I, .23; PM.III, 551,460; PM.IV, 267; PM.V, 256; Quibell, Excavation Saqqara in 1905-1906, 4-5, (Le Caire,1907), pl .22 (I), 27.

${ }^{10}$ Louvre C7, Untein; PN.II, 23.

${ }^{11}$ PM.III, 867 from Dyn.xxvi; PM VIII, 746; Steindorff, Cat.59 (171), pls. xxxii-cxxi, in Baltimore (Md), Walters Art Gallery, 22, 76.

12 Stela no.174 (Lopez, Ehnasya season1968); P. Die.M.Carmen, Ehnasy el-Medina Heracliopolis Magna Egipto, (Madrid, 2010), 28, no.1781, fig31, no.1789 , 28; 120 Year of Spanish Archaeology in Egypt, (Madrid, 2009), 183.

${ }^{13}$ About titles and epithets see: Ward, Index of Egyptian Administrative and Religious Titles of The Middle Kingdom (Beirut, 1982).

${ }^{14}$ HT.II, 14; CGC 20609; Ward, Index of Egyptian Administrative and Religious Titles, 104, no.857.a, and no. 1156.

${ }^{15}$ Stela no.210 for Ddj (Lopez, Ehnasya season,1968) .

${ }^{16}$ Baud, 'Famille Royale et sous l'Ancien Empire Égyptien', BdE 126 (1999), $107 \mathrm{ff}$.

${ }^{17} \mathrm{~Wb}$, II,446,1Z ; Coulon, 'Les Uraei Gardiens du Fétiche Abydenien', in: Devauchelle,D.(ed), La XXVIe Dynastie:Continuités et Ruptures,Actes des Journées d'Etudes Tenues à l'Université deLille26-27, Novembre, 2004 (Paris,2006), 90; De Meulenaere, Le Clergé Abydénien d'Osiris à la Basse Epoque', in: Mélanges J.Vergote, OLP 617(1975-1976), 138.

${ }^{18}$ El-Hitta, La Revue du Caire, Numéro Spécial 33, No. 175 (1955),50; Lilyquist,'Early Middle Kingdom Tombs at Mitrahina', JARCE 11(1974), 27-30

${ }^{19}$ G. Lapp, Die Opferformel des Alten Reiches, (Mainz, 1986); Barta, Aufbau und Bedeutung der Altägyptischen Opferformel, (München, 1968); Wilkinson, Dictionary of Ancient Egypt, (London, 2005), 176177; Cauville, Offerings to the Gods in Egyptian Temples, (Paris, 2012), 63.

${ }^{20}$ Griffiths, 'Osiris', in:L̈̈ IV (1982), 623-634; Lurker, An Illustrated Dictionary of the Gods and Symbols of Ancient Egypt, (London,1980), 92-94; Erman, A Handbook of Egyptian Religion , (London,1907), 16; Budge, The Gods of the Egyptians, (London,1904), 113-118.

${ }^{21}$ Badawy 'La Stéle Funéraire sous L'Ancien Empire son origine et son fonctionnement', ASAE 48 (1948), 224; Altenmüller, 'Anubis', in: L̈̈ I (1975), 327-333.
} 
nether world. ${ }^{22}$

e- The stela is of the "false doors" type, which was in the shape of doors ${ }^{23}$ and bore offerings to gods. ${ }^{24}$ This type was known from - at least- the third dynasty, ${ }^{25}$ and it became popular in the first Intermediate Period. ${ }^{26}$ By the beginning of the Middle Kingdom, the false door stelae became as the ordinary stelae. ${ }^{27}$ The difference between the function of the ordinary funerary stelae and the false doors was that the first aimed to confirm the owner's possession of his tomb, while the false door aimed to confirm the relationship between the owner and the gods of the nether world, which the formulae on these stela dedicated to them, and also to help the deceased to get in and out his tomb. ${ }^{28}$

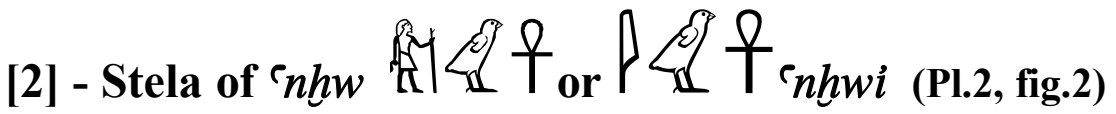

A stela of the false door' is belonging to an individual called "` $n h w$ or 'nhwi". Material: limestone. Measurement: $76 \times 72 \times 16 \mathrm{~cm}$. Place of preservation: Ihnasya El-medina magazine (Inv. Nr. 4083/1- 2010 Ihnasya). State of preservation: The relief and hieroglyphs are in a fairly good state of preservation, rendered in sunken relief.

\section{Description}

The stela is stolen from a site near the cemetery of the First Intermediate Period and Middle Kingdom at Ihnasya. It is lost most its upper part, through a comparison of other stelae with what remains of this stela, most of its details can be reconstructed. It contained hieroglyphs for the titles and name of the stela's owner 'nhw or 'nhwi. The jamb and the lintel of the stela are lost .The hieroglyphs were written in three registers. The first one represents the remains of the right side, including the right lintel, which contained horizontal hieroglyphs beginning from the middle, with two formulae of htp di $n s w$. The first formula usually is containing the standard formula for the god Osiris, an offering of invocations, the title and the name of the owner of the stela 'nhwi. Most of the second register on the left side of the stela is also lost, except the lower part of the stela owner's feet. The upper part of the third register on the middle of the stela is lost. There is a figure of the stela's owner 'nhwi who is seated before the offering table in the center of the stela and surrounded by a molding in the shape of square. This table usually supported a woven mat and the heap of food, including goose. Most of the traditional offering formula is intact: An offering consisting of $\{a$

\footnotetext{
${ }^{22}$ Seeber, 'Untersuchungen zur Darstellung des Totengerischts im Alten Ägypten', MÄS 35 (1976), 154ff; H.Willems,'Anubis as a Judge', in: H.Willemes \& Others, Egyptian Religion the Last Thousand Years, Studies Dedicated to the Memory of Jan Quaegebeur OLA 84 (1998), 719-743; RÄRG, 568-576.

${ }^{23}$ It also beard the names of the real doors such as : $r w t$ ' $n d$ r $r 3 \mathrm{pr}$ see: $W b$ II, 397, 8; Wb II, 403, 13;G.Lapp, 'Die Stelenkapelle des Kmz aus der 13.Dynastie', MDAIK 50 (1994), 231-233; Badawy, 'La stéle funéraire Égyptienne à Ouverture Axiale', BIE 35 (1954), 25.

${ }^{24}$ F.Le Corsu,'Stele-portes,Egyptiennes a elements emboites d'Epoque Greco-Romaine', RdE 20 (1986), 110.

${ }^{25}$ J.L.Smith, Paintings from Egypt, An Exhibition in Celebration of the Fifth Anniversary of the Department of Egyptology (Brown, 1998), 24.

${ }^{26}$ C.Ziegler, Catalogue des stéles, peintures et reliefs Égyptiens de L'Ancien Empire et de la Premiére Periode Intermédiaire, (Paris,1995), 58ff.

${ }^{27}$ H.Evers, Staat aus dem Stein,II , (München,1929), 83.

${ }^{28}$ Jequier, Manual d'Archeologie Egyptienne, 350ff; J.Capart ,'Egypte pharaonique,Chars a Voile en Egypte', CdE 32 (1941), 206ff.; K. Martin,'Stele ', in: LÄ,VI (1982), 1; H.Saleh,'Investigating Ethnic and Gender Identities on Wooden Funerary Stelae from Libyan Period in Egypt', in: BAR International Series 1734 (2007), 13.
} 
thousand of bread , a thousand of beer, a thousand of oxen, a thousand of fowl, a thousand of ointment-jars and a thousand of clothing which belonging to 'nhwi. The stela's owner figure is seated before the offering table and he is holding a piece of cloth in the left hand, gripping it to his chest while the right hand extended towards the table. 'nhwi is depicted sitting on a low lion leg chair with back support. Below the owner's figure are names of scared oils, which are carved around the sides of a false door shape. This false door was believed to help the spirit of 'nhwi to go back and forth through it, enabling him to see what happened outside the tomb. Upon the false door, there is a remnant of the determinative for scared oil which should be $s \underline{t}-(j)-h b$, the odour of festivals ${ }^{29}$ and the name of $h k n w$ oil of parsing ${ }^{30}$. On the left side of the false door there are names of $t w 3(w t)$ anointing oils ${ }^{31}, h t t$ (nt) 935 the best of cedar oil ${ }^{32}$ and $h t t(n t) t h n w$ the best of Libyan oil. ${ }^{33}$ Most of the left side of the false door is lost which should be begin with the name of "sft $\underline{n}^{134}$ juniper oil ${ }^{35}$, in the lower of this side there is the name of $n-h n m,{ }^{36}$ "union oil" also has been translated as $n \check{m} m-$ slave $^{37}$.

\section{Texts}

Most of the upper part of the lintel was lost, which usually contained in its upper part horizontal hieroglyphs extending from its middle, with two formulas of htp -di-nsw, the details of the first one which on the right side are lost:

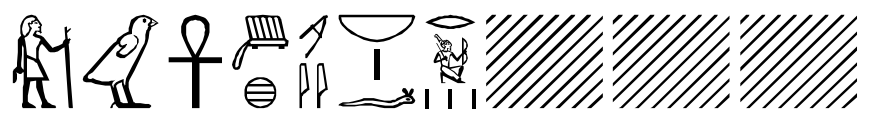

[htp di nsw Wsir nb ddw prt ḩrw t k3w 3pdw nt imj-]r mšc mrj nb.f im3hww `nhww.

[May the king give a boon (to) the god Osiris lord of Busiris, invocation offerings from bread, oxen, and fowl for the commander] of the army, the beloved by his master the revered 'nhw.

All details of the second lintel, on the left side were lost. The third register contained a figure of the stela's owner 'nhwi, who is seated before the offering table which usually supported a woven mat and the heap of food, such as goose. There is most of the traditional offering formula, so we can know they were: "An offering consisting of a thousand of bread\}, a thousand of beer, a thousand of oxen, a thousand of fowl, a thousand of ointment-

\footnotetext{
${ }^{29}$ Wb IV, 350; D. Meeks, Annee lexicographique III (1979) (Paris, 1982), 278; Abdel Hamid Shimy, Parfum et parfumerie dans l'Ancienne Egypte (de l'Ancien Empire a la fin du Nouvel Empire), vol. I, (Lyon, 1997), 3031.

${ }^{30}$ Wb III, 181, 5-6; W.A.Hayes, Scepter of Egypt, I (New York,1953), 117; Abdel Hamid Shimy, Parfum et parfumerie dans l'Ancienne Egypte, 29-30.

${ }^{31} \mathrm{~Wb}$ V, 251, 4; Hayes, Scepter of Egypt, 117; Abdel Hamid Shimy, Parfum et parfumerie dans l'Ancienne Egypte, 33.

${ }^{32}$ Wb I, 228, 6; Wb III, 28, 10-11;Hayes, Scepter of Egypt, I, 117; Abdel Hamid.Shimy, Parfum et parfumerie dans l'Ancienne Egypte, 33-34.

${ }^{33}$ Wb V, 394, 9; Hayes, Scepter of Egypt, 117; Abdel Hamid Shimy, Parfum et parfumerie dans l'Ancienne Egypte, 35.

${ }^{34}$ Gardiner, $A E O, \mathrm{I}, 8$.

${ }^{35} \mathrm{~Wb}$ V, 118, 12-13; Hayes, Scepter of Egypt, 2, who translated sft as 'Syrian Balsam'; Abdel Hamid.Shimy, Parfum et parfumerie dans l'Ancienne Egypte, 30-31.

${ }^{36} \mathrm{~Wb}$ II, 319.

${ }^{37}$ Wb II, 319, 1-2; Hayes, Scepter of Egypt, 117; Abdel Hamid.Shimy, Parfum et parfumerie dans l'Ancienne Egypte t, 30-31
}

- 56 - Three incomplete limestone stelae from Ihnasya El-Medina (Herakleopolis Magna) 
jars and a thousand of clothing which belonging to \{the spirit of ' $n h w i$. The text is as follows:

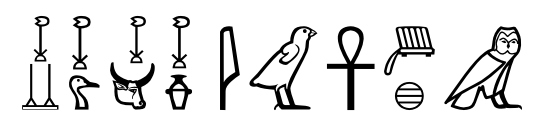

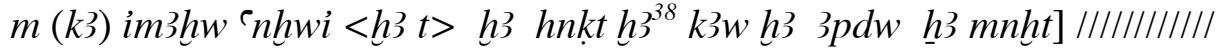

to (the spirit of) the revered 'nhwi (an offering consisting of) $<a$ thousand of bread $>, a$ thousand of beer, a thousand of oxen, a thousand of fowl, a thousand of ointment-jars and a thousand of clothing.

\section{Comment}

a- This type of stela dates from the First Intermediate Period and the beginning of Middle Kingdom, because the shape of the stela was very popular during this period $^{39}$.

b- The owner of the stela's name is mentioned two times, once as ' $n h w$ and the second time as 'nhwi. The second shape did not appear before, so this is the first time it is represented at Ihnasya el-Medina, while the first shape appeared at the end of the First Intermediate Period from the time of Montohotep -Nebheptre ${ }^{40}$, and became very common during the Twelfth and Thirteenth Dynasties ${ }^{41}$.

c- The main title of "anxw" was the commander of soldiers, while the traditional titles are: who beloved from his master, these titles are:

[imj-]r mš mry nb.f im3hw 'nhw' 'the commander of the army, the beloved by his master, the revered ' $n h w$ '. These titles were found on many stelae at Ihnasya elMedina $^{42}$, and in many tombs from this period. ${ }^{43}$

d- The earliest known complete list of the seven scared oils appeared in the Pyramid Texts; ${ }^{44}$ later examples appeared in tombs of the Sixth Dynasty. ${ }^{45}$ Furthermore,

\footnotetext{
${ }^{38} \mathrm{~h} 3$ referred to the numerous offerings dedicated to the kA of the deceased, see: Assmann, Death and Salvation in Ancient Egypt, (London, 2005), 96-102; Nicola, Living with the Dead, Ancestor Worship and Mortuary Ritual in Ancient Egypt (Oxford, 2013), 13-15; R. Clark, Myth \& Symbol in Ancient Egypt, (London, 1959), 231-234.

${ }^{39}$ Revise many similar stelae from the same periods inside Ihnasya necropolis itself or outside it, see the introduction.

${ }^{40}$ PM.VIII, 267; Paris Musee National du Louvre, E.17365; J. Vandier, Manuel d'Archeologie Egyptienne III, Les grandes époques, La Statuaire (Paris,1958); E. Delange,Catalogue des Statues Egyptienne du Moyen Empire ,Musee du Louvre (Paris,1987), 180-181; Urk.I ,92,7; K. Sethe, 'Der Name'Merui-tensi' und die Entwicklung der Filiationsangabe bei den Agypten', Z̈̈S 49 (1967), 98 ; PN. I, 68.

${ }^{41} P M$. V, 20, 48, 52, 96, 247-248; L. Habachi, Elephantine IV. The Sanctuary of Heqaib (Cairo, 1985), AV 33, 166 (1),fig 1, pl.211(d); in Copenhagen, Ny Carlsberg Glyptotek, AE.I.N.28; Koefoed. Peterson, Cat. des Statues 19 (26), 80, 83, pl.27; Farina, Regio Museo 1931, fig on.42 (right); L.Curto, Antica Egitto nel Museo Egizio di Torino (1984), fig.on.107; J. DeMorgan, Catalogue des Monuments et Inscriptions de l' Egypte Antique (Vienna, 1894), 26; A. Kamal, Tables d'offrands, CGC, 42-3,50-2;T.E.Peet, The Cemeteries of Abydos, III (London,1913), pls.23(1), 29 (9), 25(7),35, 119-20 (23-4); W. Spiegelberg \& Portner, Aegyptischen Grabsteine und Denksteine aus suddeutschen Sammlungen I, pls.9 (14), 12 (20), 10,12.

${ }^{4}$ Stela no.210 for Ddj (Lopez, Ehnasya season,1968) .

${ }^{43}$ For example the tomb of Impy in Kom-El-Fakhry Necropolis, see: C.Lilyquist,'Early Middle Kingdom Tombs at Mitrahina', JARCE 11(1974), 29.

${ }^{44}$ W.A.Hayes, Scepter of Egypt I, 117; S.Tawfik, 'Die Alabaster Paletten für die Sieben Salböle im Alten Reich', GM 30(1978), 77ff; H. Altenmüller, 'Das Ö1Magazin im Grab des Hesire', SAK 4 (1976), 13ff; J. Malek, 'An Ointment-Slab of Sekhemptah', GM 33 (1979), 35-40.

${ }^{45}$ W. K.Simpson, The Mastaba of Qar and Idu at Giza, (Boston,1976), figs. 40-41.
} 
during both the Old Kingdom and the First Intermediate Period, the names of these oils are mentioned on monuments inside and outside Egypt. ${ }^{46}$ The seven sacred oils were used in the daily service of the temples and tombs to anoint the statue of the god or the deceased. ${ }^{47}$ The Ancient Egyptians anointed the mummy with these oils before wrapping it with linen as this served to bind the linen wrappings to the body. ${ }^{48}$ These oils were also connected with the opening of the mouth ritual. ${ }^{49} \mathrm{In}$ addition to these functions in the funerary rituals and daily service in the temple, the seven sacred oils were used also by the Egyptians in their daily life. ${ }^{50}$

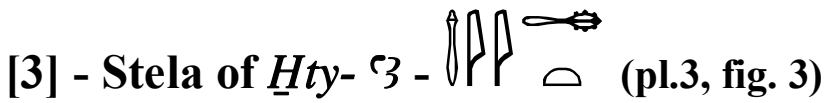

A fragment of a stela belonging to an individual called $\underline{H} t y-{ }^{-}$.
Material: limestone.
Measurement: 1 x 22 x $15 \mathrm{~cm}$.

Place of preservation: Ihnasya El-Medina Magazine (Inv.Nr. 4083/2- 2010 Ihnasya).

State of preservation: The relief and hieroglyphs are in a fairly good state of preservation, rendered in sunken relief.

\section{Description}

It is suggested that the stela was stolen from a site near from cemetery of The First Intermediate Period at Ihnasya. This part of the stela represents the right side, which indicates that the stela consisted of the upper part, which contained two horizontal lines of hieroglyphs starting from the left side of the stela and connected with two vertical lines in the right of the stela. These two horizontal lines should begin with the famous formula htpdi-nsw, which is followed by Osiris and Anubis. The lower part of this stela contained a horizontal line of hieroglyphs, which also ran from left to right. It probably began with the formula of Anubis, because it finishes with the name of the god Imyut.

It can be suggested that the right side of the stela contained two vertical lines of hieroglyphs, similar to those on the left side, written vertically. From my comparison studies, It can be suggested that the middle part of this stela contained the jamb and the lintel of the stela, with a figure of the stela's owner, hty-?3, who was seated before the offering table in the center of the stela and surrounded by a molding in the shape of square. This table usually contained on its top a woven mat and the heap of food, and a goose with a traditional offering formula: "An offering consisting of a thousand of bread a thousand of beer, a thousand of oxen, a thousand of fowl, a thousand of ointment-jars and a thousand of clothing to the spirit of hty- 3 . It could be suggested that the middle of this stela was finished with a false door shape to help the spirit of the hty-? 3 go back through it and to see what was happening outside the tomb.

\footnotetext{
${ }^{46}$ N. Kanawti, The Rock Tombs of El-Hawawish, The Cemetery of Akhmim 10 vols. (Sydney, 1980-1992), vol. IV, pl.9, figs.30-32; Idem, El-Hawawish, vol.X, pl.2, fig.10 .

${ }^{47}$ Z. Hawass, 'A Unique Old Kingdom Headrest and Offering Tablet of Seven Scared Oils Found at Saqqara', Memnonia 9 (1998), 158, pl .XIX.B.

${ }^{48}$ W. A.Hayes, Scepter of Egypt I, 117.

${ }^{49}$ T.G.Baly, 'Notes on the ritual of opening the mouth', JEA 16 (1930), 173-186; A.M.Blackman ,'The Rite of Opening the Mouth in Ancient Egypt and Babylon', JEA 10 (1924), 47-59; J. Gayon, Rituels Funeraires de l'Egypte Ancienne (Paris, 1972), 89-90; Abdel Hamid.Shimy, Parfum et parfumerie, 26-119; R. Germer, 'öle' in: $L \ddot{A}$ IV (1982), 554-555.

${ }^{50}$ Z. Hawass, Memnonia IX, 158.
} 


\section{Texts}

Most of the upper part of the stela was lost, especially the right side which usually contained horizontal hieroglyphs written from left to right, the remaining two lines read as follows:

The first line:

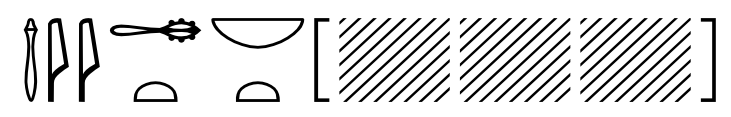

[prt hrw t k3w 3pdw nt im3hw hr ntr ? $\left.^{3}\right]<p t>n b . t^{51}$ hty-?

[Invocation offerings of bread, oxen, and fowl for the revered from the great god] master of the sky hty-?3.

The second line:

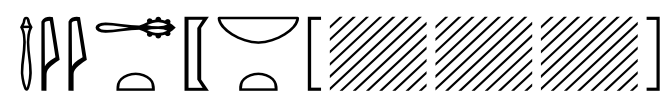

[prt hrw t k3w 3pdw nt im3hw hr ntr 93$] n b . t^{52}$ pt hty-?3.

[Invocation offerings of bread, oxen, and fowl for the revered from the great god] master of the sky hty-e3.

The right side of the stela contains two verticals lines of hieroglyphs. The outer one reads as follows:

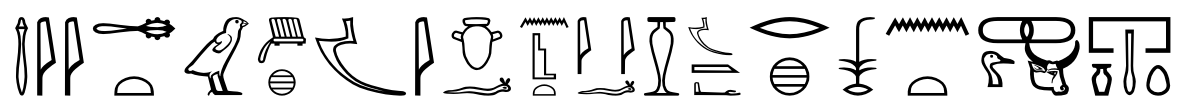

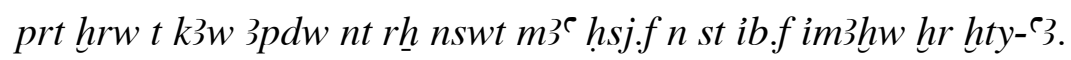

Invocation offerings of bread, fowl for the real king's acquaintance, the praised one, who is seated in his heart, the revered hty-?3.

The inner vertical line as following:

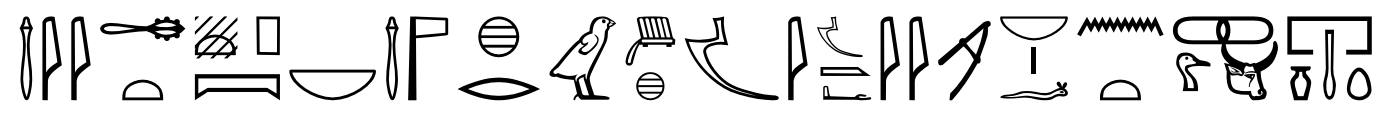

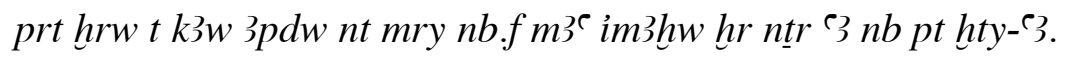

Invocation offerings of bread, oxen, and fowl for the real beloved of his master, the revered one, from the great god lord of the sky hty-?3.

In the lower part of the stela are remains of horizontal hieroglyphic writing, written from right to left, which its beginning is lost, as follows:

\footnotetext{
${ }^{51}$ The writer mistakenly wrote $p t$ nb.t instead of $\mathrm{nb} \mathrm{pt}$ as the line in the upper part of the stela.

${ }^{52}$ The writer also mistakenly wrote $n b . t$ instead of $\mathrm{nb}$ as the inner vertical line.
} 


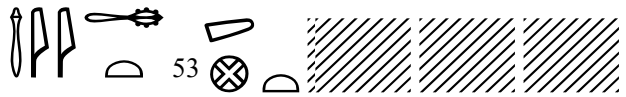

[prt hrw t k3w 3pdw nt im3hw hr Imj-w]t? hty-?3

[Invocation offerings of bread, oxen, and fowl from the god $>$ Imy.w] $t^{54}<$ for the revered one>, hty-? .

\section{Comment}

a- Undoubtedly the style of this stela is different from the other stelae $(1,2)$, this style has not been discovered before in cemeteries of the First Intermediate Period, but we have many examples from the cemetery of the Middle Kingdom at Ihnasya. That means that this style was developed during this time. ${ }^{55}$

b- The owner of the steal's name hty-? 3 was unknown before in Ihnasya, but it was known during the Middle Kingdom. ${ }^{56}$ There is a stela in the Leiden Museum had the name hty- ${ }^{3} t .{ }^{57}$ While the origins of this name are found in the Ninth and Tenth Dynasties, where most of Ihnasya's kings bore this name hty, it is also a typical name among common people in Ihnasya and others necropolises in the First Intermediate Period and the Middle Kingdom. For instance the owner of tomb number $\mathrm{V}$ in Asuit necropolis was called hty $I^{58}$, and another hty occupied tomb number III in the Asuit necropolis. ${ }^{59}$ Probably adding the epithet 33 to a name for giving honor and glorification to his owner, and the meaning of the name is "The great hty".

\footnotetext{
${ }^{53}$ It can be suggested that the writer either mistakenly wrote the determinative of the town instead of the
} main determinative $Q$ of the word imy-wt, or he used the determinative of the place with the word imy-wt as this word means "who is in the place of mummification" an epithet to Anubis .Or probably the missing part indicated to a geographical district ended with

${ }^{54}$ The meaning of the word is uncertain, it takes the shape of an animal skin without a head, holding onto a stick, inside a pan, the tail of the animal usually ended with the lotus flower. This skin was known as "the son of the cow hesat", which was regarded as the mother of Anubis. This skin was used from the First Dynasty and was related to mummification, the role of Anubis in collecting the secretions of Osiris during its mummification and putting them in a sacred leather bottle which was known as the imy-wt, which became an epithet to Anubis which meant "who is in the place of mummification" or "who is in the wrappings" as Anubis was associated with mummification and responsible for wrapping Osiris. This epithet appeared with the most common epithet of Anubis $n b t 3 \underline{d} s r$ 'lord of the sacred land' on many stelae, especially stelae with the htp di $n s w$ formulae. For more details see: U. Köhler, Das Imiut (Wiesbaden, 1975), 346; R. Wilkinson, The Complete Gods and Goddess (London, 2003), 187-192; M.L.Bierbrier, The British Museum Hieroglyphic Texts from Egyptian Stelae ETC, Part 2 (Cambridge, 1987), pl. 48; S. Ikram, Death and Burial in Ancient Egypt (Cairo, 2015), 36.

${ }_{55}^{5}$ Spanish missions at Ihnasya el-Medina, registration numbers:199, 208, and 408.

${ }^{56}$ PN.I, p277-27.

${ }^{57}$ J.H.Holwerda\& P.A.A.Boeser, Wijngoarden in der Beschrijung van de Egyptische Ver Zameling in het Rijksmuseum van Oudheden te Leiden, Deel I -XIV, Leiden und S, Gravenhage 1905-1932, Leiden V.109.

${ }^{58}$ For the details about the tomb, see PM, IV, 264; P. Montet, Les Tombeaux des Siout et Deir Rifeh, Kémi III (1930-1935), 107-111; H. Brunner, Die Texte aus den Gräbern der Herakleopolitenzeit von Siut ( ÄF3; Glückstadt ,1937), 11ff; M.El-Khadragy \& J.Kahl, 'The First Interrmediate Period Tombs at Asyut Revisited', SAK 32 (2004), .241f; M.Zitman, TheNecropolis of Assiut, (Uitgeverij Peeters and Department Oosterse Studies (Leuven- Paris -Walpole, 2010), 39.

${ }^{59}$ For the details about the tomb, see $P M$ IV, $260 \mathrm{ff}$ 
c- The main titles of hty- 3 were: $\left\{r h\right.$ nswt $m 3^{\odot}$ mrj.f $n$ st $\left.i b . f\right\}$, the king's real acquaintance, his beloved one, and who is seated in his heart. This formula is attested since the Twelfth Dynasty until the Thirteenth Dynasty. ${ }^{60}$

\begin{tabular}{|l|l|l|l|}
\hline Stela & $\begin{array}{c}\text { Owner's } \\
\text { name }\end{array}$ & \multicolumn{1}{|c|}{ Titles } & \multicolumn{1}{|c|}{ Date } \\
\hline No.1 & Ipi & $\begin{array}{l}\text { The real king's acquaintance, the } \\
\text { beloved by his master, the praised one. }\end{array}$ & $\begin{array}{l}\text { The First Intermediate } \\
\text { Period or the beginning } \\
\text { of the Middle Kingdom. }\end{array}$ \\
\hline No.2 & $3 n h w w\left({ }^{\prime} n h w i\right)$ & $\begin{array}{l}\text { The commander of the army, the } \\
\text { beloved by his master. }\end{array}$ & $\begin{array}{l}\text { The First Intermediate } \\
\text { Period or the beginning } \\
\text { of the Middle Kingdom. }\end{array}$ \\
\hline No.3 & hty-? & $\begin{array}{l}\text { The real king's acquaintance, praised } \\
\text { one, and who is seated in his heart. }\end{array}$ & The Middle Kingdom. \\
\hline
\end{tabular}

\section{Facsimiles \& plates of the stelae}
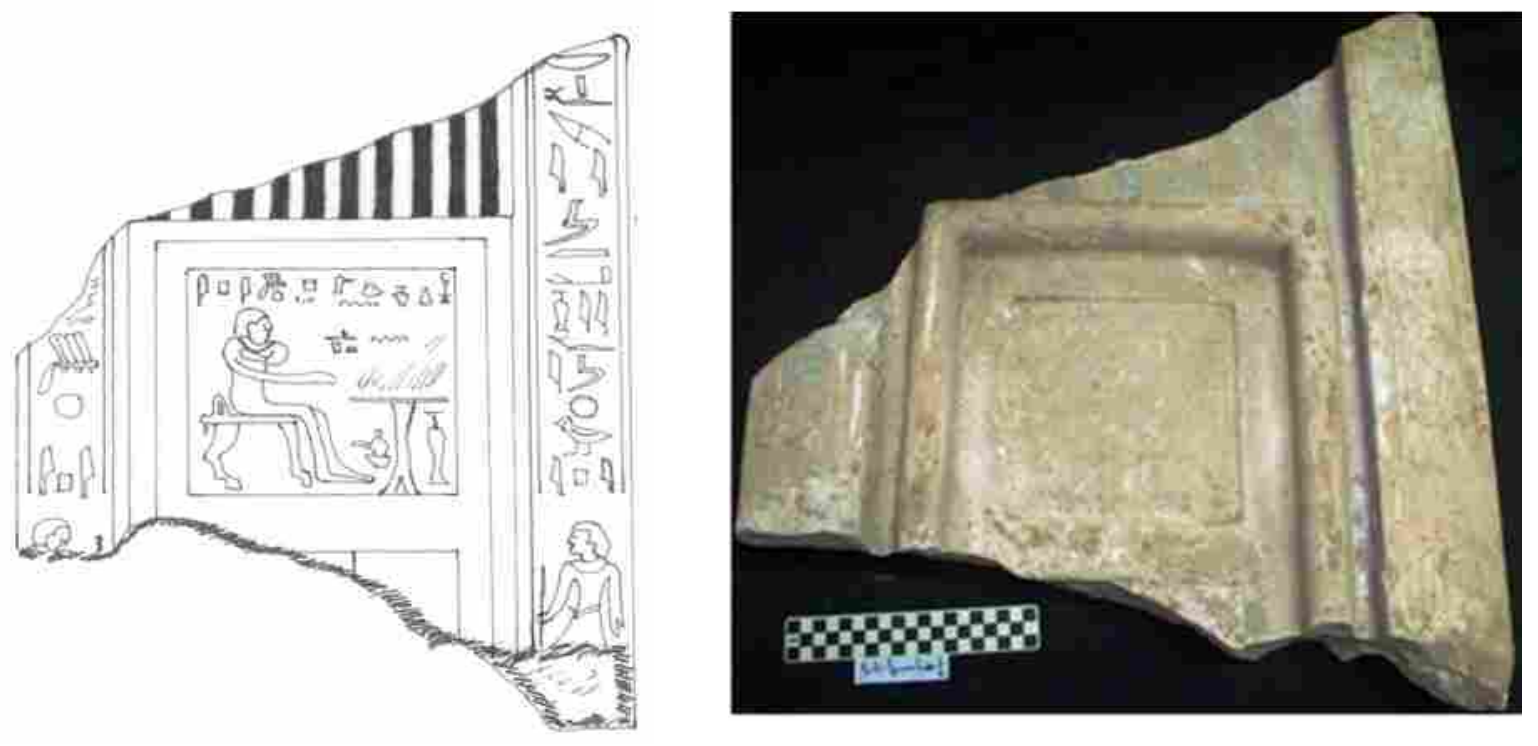

Fig. 1 \& Pl. 1: Stela of Ipi

\footnotetext{
${ }^{60}$ W.Grajetzki, Die hochsten Beamten der agyptischen Zentralverwaltung Zur Zeit des Mittleren Reiches (Berlin, 2000 ), 225; S. Quirk, 'The Regular Titles of the Late Middle Kingdom', RdE 35 (1984), 108 (no.7); W.A.Ward, Index of Egyptian Administrative, 875a; D.Jones, An Index of Ancient Egyptian Titles, Epithets and Phrases of the Old Kingdom II (Oxford, 2000), Nr.3268.
} 

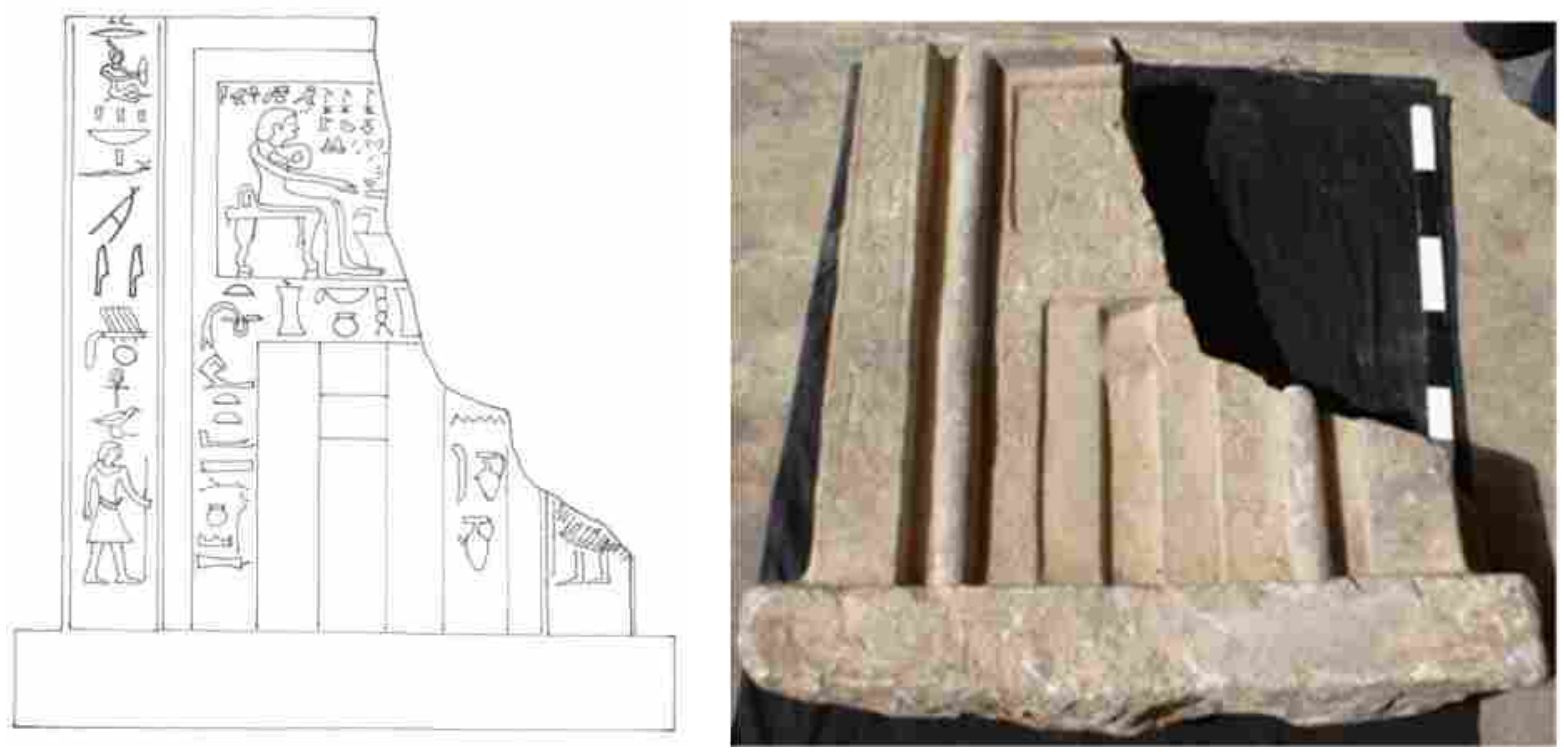

Fig. 2 \& Pl. 2: Stela of 'nhww or `nhwi 

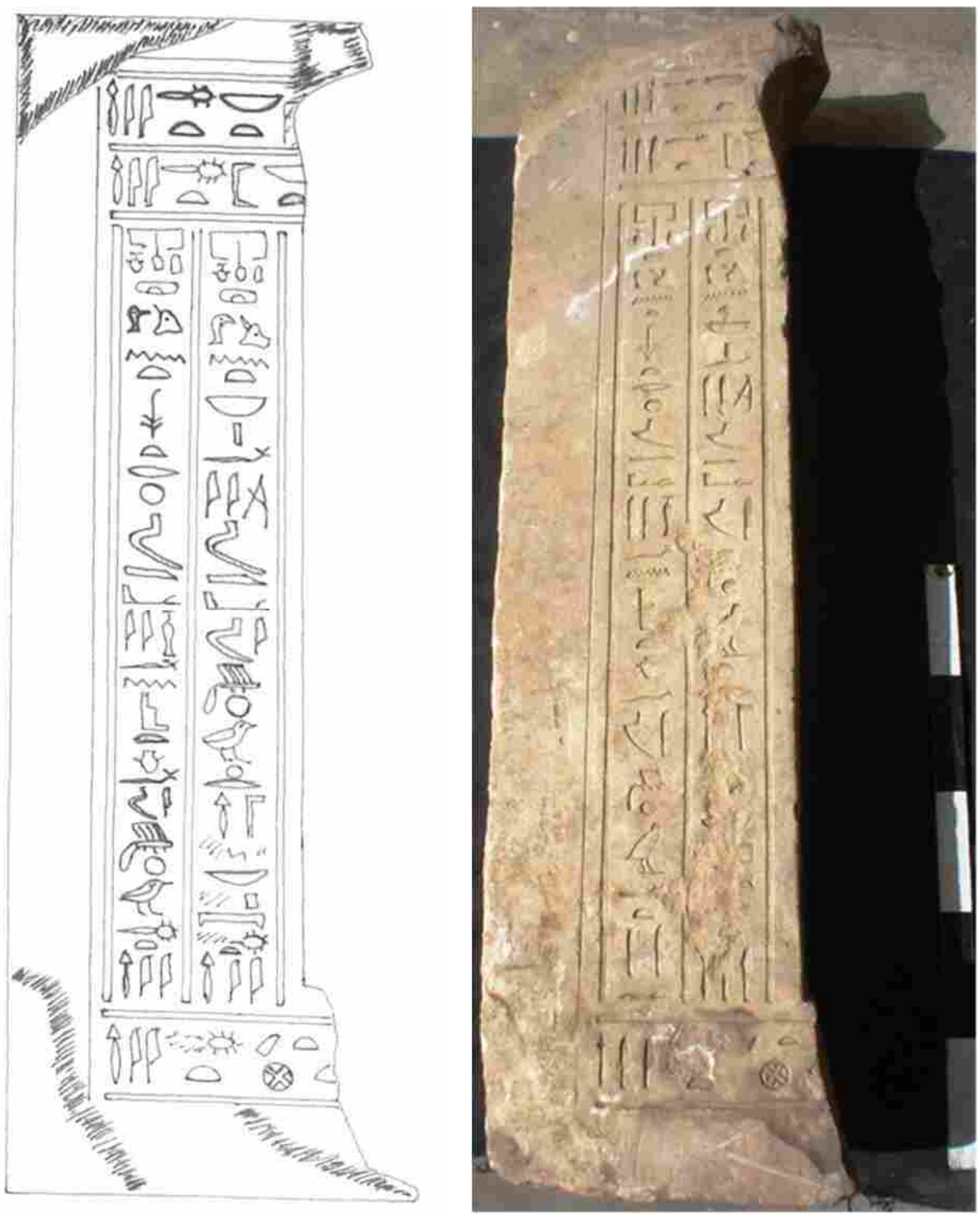

Fig. 3 \& Pl. 3: Stela of $h$ ty- $^{-3}$ 


\section{REFERENCES}

- Altenmüller H., 'Das Ö1Magazin im Grab des Hesire', SAK 4 (1976).

- _ _ 'Anubis ', in: LÄ I (1975), 327-333.

- Anthes R., 'Die Felseninschriften von Hatnub', in: K.Sethe (ed.), Untersuchungen zur Geschichte u.Altertamskunde Ägypten, herausg V. G. Steindorff.Bd.g., (Leipzig,1928).

- Assmann J., Death and Salvation in Ancient Egypt, (London, 2005).

- Badawy A., 'La stéle funéraire Égyptienne à Ouverture Axiale', BIE 35 (1954).

- Baly T.G.,

- Barta, 'Notes on the ritual of opening the mouth', JEA 16 (1930), 173-186 Aufbau und Bedeutung der Altägyptischen Opferformel, (München,1968).

\section{- Baud, \\ (1999).}

- Bierbrier M.L., The British Museum Hieroglyphic Texts from Egyptian Stelae ETC, Part 2 (Cambridge, 1987).

- Blackman A., 'The Rite of Opening the Mouth in Ancient Egypt and Babylon', JEA 10 (1924), 47-59

- Brunner H., $\quad$ Die Texte aus den Gräbern der Herakleopolitenzeit von Siut (ÄF3; Glückstadt, 1937).

- Budge W., The Gods of the Egyptians, (London,1904).

- Carmen P. Die.M.,

- Cauville S.,

- Clark R.,

- Coulon,

- Curto L., Ehnasy el-Medina Heracliopolis Magna Egipto, (Madrid, 2010).

Offerings to the Gods in Egyptian Temples, (Paris, 2012). Myth \& Symbol in Ancient Egypt, (London, 1959).

'Les Uraei Gardiens du Fétiche Abydenien', in: Devauchelle,D.(ed), La XXVIe Dynastie:Continuités et Ruptures, Actes des Journées d'Etudes Tenues à l'Université deLille26-27, Novembre, 2004 (Paris, 2006), 85-108.

- De Meulenaere, Le Clergé Abydénien d'Osiris à la Basse Epoque', in: Mélanges J.Vergote, OLP 6\7(1975-1976), 132- 140.

- Delange E., $\quad$ Catalogue des Statues Egyptienne du Moyen Empire, Musee du Louvre (Paris, 1987).

- De-Morgan J., Catalogue des Monuments et Inscriptions de l'Egypte Antique (Vienna, 1894).

Fouilles à Dahchour, (Vienne, 1895).

- $\overline{\text { E-Khadragy }}$ M. \& Kahl J.,

- El-Hitta,

- Erman A.,

- Evers H.,

- F.Le Corsu,

- Gardiner A.,

- Garlstang, 'The First La Revue du Caire, Numéro Spécial 33, No.175 (1955). A Handbook of Egyptian Religion, (London, 1907). Staat aus dem Stein,II, (München,1929).

'Stele-portes,Egyptiennes a elements emboites d'Epoque GrecoRomaine', RdE 20 (1986).

'The Baptism of the Pharoh', JEA 36 (1950), 3-12.

- Gayon J.,

- Germer R., The Burial Customs of Ancient Egypt as illustrated by Tombs of the Middle Kingdom, (London, 1907).

- Grajetzki W., Rituels Funeraires de l'Egypte Ancienne (Paris, 1972). 'öle' in: LÄ IV (1982), 554-555 Die hochsten Beamten der agyptischen Zentralverwaltung Zur Zeit 
- Griffiths,

- Hawass Z.,

- Hayes W.A.,

- Holwerda J.H. \& Boeser P.A.A.,

- Ikram S.,

- Jequier,

- Jones D.,

- Kanawti N.,

- Köhler U.,

- Lapp G.,

- Lapp G.,

- Lilyquist C.,

- Lopez,

- Lurker,

- Malek J.,

- Martin K.,

- Meeks D.,

- Montet P.,

- Newberry,

- Nicola,

- Peet T.E.,

- Petrie,

- Quibell,

- Quirk S.,

- Rawash H.,

- Saleh H.,

- Seeber,

- Sethe K.,

- Shimy Abdel Hamid,

- Simpson W. K.,

- Smith J. L., des Mittleren Reiches (Berlin, 2000 ).

'Osiris', in: LÄ IV (1982), 623-634.

'A Unique Old Kingdom Headrest and Offering Tablet of Seven Scared Oils Found at Saqqara', Memnonia 9 (1998).

Scepter of Egypt, I (New York, 1953).

Wijngoarden in der Beschrijung van de Egyptische Ver Zameling in het Rijksmuseum van Oudheden te Leiden, Deel I -XIV, (Leiden und S, Gravenhage 1905-1932).

Death and Burial in Ancient Egypt (Cairo, 2015).

Manual d'Archeologie Egyptienne (Paris-1998).

An Index of Ancient Egyptian Titles, Epithets and Phrases of the Old Kingdom II (Oxford, 2000).

The Rock Tombs of El-Hawawish, The Cemetery of Akhmim 10 vols. (Sydney, 1980-1992).

Das Imiut (Wiesbaden, 1975).

'Die Stelenkapelle des Kmz aus der 13.Dynastie', MDAIK 50

(1994), 231-233.

Die Opferformel des Alten Reiches, (Mainz, 1986).

'Early Middle Kingdom Tombs at Mitrahina', JARCE 11(1974), 27 30.

Ehnasya season, 1968

An Illustrated Dictionary of the Gods and Symbols of Ancient Egypt, (London, 1980).

'An Ointment-Slab of Sekhemptah', GM 33 (1979), 35-40.

'Stele ', in: L̈̈, VI (1982), 1-4.

Annee lexicographique III (1979) (Paris, 1982).

Les Tombeaux des Siout et Deir Rifeh,Kémi III (1930-1935).

Beni Hasan I, (London, 1893).

Living with the Dead, Ancestor Worship and Mortuary Ritual in Ancient Egypt (Oxford, 2013).

The Cemeteries of Abydos, III (London,1913).

Deshasheh. Egypt Exploration Fund Fifteenth Memoir, (London, 1898).

Excavation Saqqara in1905-1906, (Le Caire, 1907).

'The Regular Titles of the Late Middle Kingdom', RdE 35 (1984), 101-110.

'Two Unpublished Stelae from Ihnasya EL-Medina', The scientific magazine of South Valley University, vol. 9 (2014), 505-525.

'Investigating Ethnic and Gender Identities on Wooden Funerary Stelae from Libyan Period in Egypt', in: BAR International Series 1734 (2007).

Untersuchungen zur Darstellung des Totengerischts im Alten Ägypten, (Berlin, 1976)

'Der Name'Merui-tensi' und die Entwicklung der Filiationsangabe bei den Agypten', ZÄS 49 (1967).

Parfum et parfumerie dans l'Ancienne Egypte (de l'Ancien Empire a la fin du Nouvel Empire), vol. I, (Lyon, 1997).

The Mastaba of Qar and Idu at Giza (Boston,1976).

Paintings from Egypt, An Exhibition in Celebration of the Fifth Anniversary of the Department of Egyptology (Brown,1998), 
- Smith, A History of Egyptian Sculpture and Painting in the Old Kingdom, (London\&Boston, 1978).

- Speleer, Textes de Cercueils, (Paris, 1946).

- Spiegelberg W. Aegyptischen Grabsteine und Denksteine aus suddeutschen \& Portner, Sammlungen I, (Berlin, 1906).

- Tawfik S., 'Die Alabaster Paletten für die Sieben Salböle im Älten Reich', GM 30 (1978).

- Vandier J., $\quad$ Manuel d'Archeologie Egyptienne III, Les grandes époques, La Statuaire (Paris, 1958).

- Wainwright, Three Stelae From Naga el-Deir', ASAE 25 (1915), 164-166

- Ward, Index of Egyptian Administrative and Religious Titles of The Middle Kingdom (Beirut, 1982).

- Wilkinson R., Dictionary of Ancient Egypt, (London, 2005).

- $\quad$ The Complete Gods and Goddess (London, 2003).

- Willems H., 'Anubis as a Judge', in: H.Willemes \& Others, Egyptian Religion the Last Thousand Years, Studies Dedicated to the Memory of Jan Quaegebeur OLA 84 (1998), 719-743.

- Wreszinski, $\quad$ Atlas zur altaegyptischen Kulturgeschichte I, (Leipzig 1923).

- Ziegler C., $\quad$ Catalogue des stéles, peintures et reliefs Égyptiens de L'Ancien Empire et de la Premiére Periode Intermédiaire, (Paris,1995).

- Zitman M., $\quad$ The Necropolis of Assiut, (Uitgeverij Peeters and Department Oosterse Studies (Leuven- Paris -Walpole, 2010).

120 Year of Spanish Archaeology in Egypt, (Madrid, 2009). 